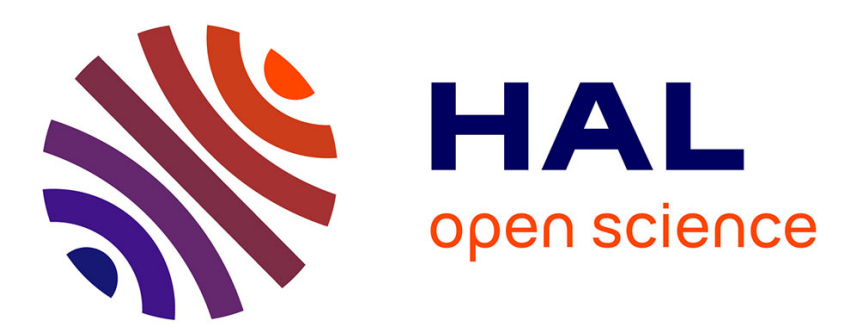

\title{
Making Monomeric Aquaporin Z by Disrupting the Hydrophobic Tetramer Interface
}

\author{
Victoria Schmidt, James N. Sturgis
}

\section{To cite this version:}

Victoria Schmidt, James N. Sturgis. Making Monomeric Aquaporin Z by Disrupting the Hydrophobic Tetramer Interface. ACS Omega, 2017, 2 (6), pp.3017 - 3027. 10.1021/acsomega.7b00261 . hal01769235

\section{HAL Id: hal-01769235 \\ https://hal-amu.archives-ouvertes.fr/hal-01769235}

Submitted on 17 Apr 2018

HAL is a multi-disciplinary open access archive for the deposit and dissemination of scientific research documents, whether they are published or not. The documents may come from teaching and research institutions in France or abroad, or from public or private research centers.
L'archive ouverte pluridisciplinaire $\mathbf{H A L}$, est destinée au dépôt et à la diffusion de documents scientifiques de niveau recherche, publiés ou non, émanant des établissements d'enseignement et de recherche français ou étrangers, des laboratoires publics ou privés. 


\title{
Making Monomeric Aquaporin Z by Disrupting the Hydrophobic Tetramer Interface
}

\author{
Victoria Schmidt* and James N. Sturgis*(i) \\ Laboratoire d'Ingenierie des Systemes Macromoleculaires, IMM, CNRS and Aix-Marseille Université, 31 Chemin Joseph Aiguier, \\ Marseille 13420, France
}

\section{Supporting Information}

ABSTRACT: The assembly of integral membrane proteins depends on the packing of hydrophobic interfaces. The forces driving this packing remain unclear. In this study, we have investigated the effect of mutations in these hydrophobic interfaces on the structure and function of the tetrameric Escherichia coli water channel aquaporin Z (AqpZ). Among the variants, we have constructed several fail to form tetramers and are monomeric. In particular, both of the mutants which are expected to create interfacial cavities become monomeric. Furthermore, one of the mutations can be compensated by a second-site mutation. We suggest that the constraints imposed

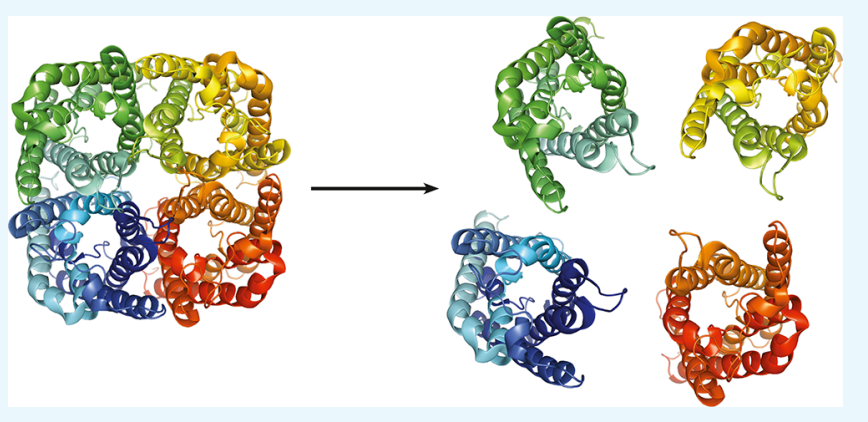
by the nature of the lipid solvent result in interfaces that respond differently to modifications of residues. Specifically, the large size and complex conformations of lipid molecules are unable to fill small interfacial holes. Further, we observe in AqpZ that there is a link between the oligomeric state and the water channel activity. This despite the robustness of both protein folding and topology, both of which remain unchanged by the mutations we introduce. We propose that this linkage may result from the specific modes of structural flexibility in the monomeric protein.

\section{INTRODUCTION}

Aquaporins (AQPs) are transmembrane channels that facilitate the passive entry of water into cells, ${ }^{1}$ a crucial mechanism in homeostasis and regulation. Discovered in the 90s, AQPs are today one of the best structurally characterized membrane protein superfamilies. AQP protomers are formed by six transmembrane spanning helices, with cytoplasmic $\mathrm{N}$ and $\mathrm{C}$ termini, ${ }^{2}$ surrounding the permeation water pore. In biological membranes, they assemble into remarkably stable homotetramers ${ }^{3,4}$ that make the minimal functional unit. In this structure, each of the four monomers appears to provide independent water channels. ${ }^{5}$

Even when several different AQPs are co-expressed in the same cell, they do not form mixed tetramers in mammalian cells. ${ }^{6,7}$ However, mixed tetramers containing two isoforms of the plant AQP, PIP1 and PIP2, have been reported. ${ }^{8}$

The problem of protein assembly in membranes is very general as many membrane proteins contain multiple subunits. ${ }^{9}$ For example, cytochrome $c$ oxidase is composed of 13 different polypeptide subunits, of which 10 are integral membrane proteins containing a total of 54 closely packed transmembrane helices. $^{10}$ Many membrane proteins also form less stable "supercomplexes" with an important functional role, as seen in the mitochondrial electron transport chains. ${ }^{11}$ Other examples include more transient higher order functional assemblies such as signaling platforms where multiple receptors assemble both in bacteria ${ }^{12}$ and in eukaryotes. ${ }^{13}$
While in membranes AQPs form tetramers, in vitro solubilized and isolated AQP tetramers show different oligomerization behaviors in detergents. Water-selective AQPs usually remain tetrameric in mild detergents, for example, Escherichia coli aquaporin Z (AqpZ) in dodecyl maltoside. By contrast, glycerol channels, such as E. coli GlpF, are often isolated as monomers. ${ }^{14}$ Mechanisms driving the efficient, specific, and stable assembly of monomers into tetramers should exist, but to date no model has clearly identified the structural features responsible for the assembly of specific stable oligomers.

As has been previously remarked, ${ }^{15}$ the easily obtainable $E$. coli water channels are a valuable working model to define the structural characteristics of AQP superfamily. AqpZ is made up of $63.8 \%$ hydrophobic amino acids, ${ }^{16}$ and the tetrameric structure has a large hydrophobic interface within the membrane thickness. The formation of oligomers is the result of protein-protein interactions, being favored over proteinenvironment interactions. GlpF was already used as a model to study the effect of the $\mathrm{V}_{71} \mathrm{M}$ mutation on the tetramerization of human Aqp2, a mutation that leads to nephrogenic diabetes insipidus. ${ }^{17}$ Some mutations have previously been shown to disrupt the tetrameric structure. In GlpF, substitution of the glutamate $\mathrm{E}_{43}$, close to the central axis between monomers,

Received: March 6, 2017

Accepted: June 14, 2017

Published: June 28, 2017 


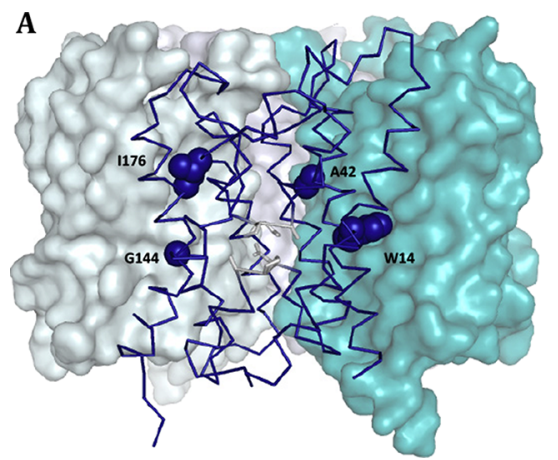

B

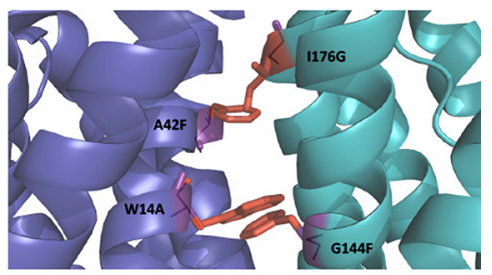

Figure 1. Structure of AqpZ tetramer and location of mutations. The crystallographic structure PDB id: $1 R C 2^{34}$ was used to prepare these figures using PyMOL. ${ }^{33}$ (A) View of the structure highlighting the interface. One monomer is shown as the C $\alpha$ chain, dark blue lines, and the surfaces of the two neighboring monomers, light blue and white, are shown to highlight the roughness of the interfaces. The residues modified in this study are shown as spheres. The bulky side chains of $\mathrm{W}_{14}$ and $\mathrm{I}_{176}$ fit into holes at the interface bordered by $\mathrm{G}_{144}$ and $\mathrm{A}_{42}$, respectively. (B) Close-up of the interface between two monomers (dark blue and turquoise), illustrating the modifications. Small residues are shown in lines, and bulky residues are shown as sticks. The native residues $\left(\mathrm{W}_{14}, \mathrm{~A}_{42}, \mathrm{G}_{144}\right.$, and $\left.\mathrm{I}_{176}\right)$ are shown in violet color, and the mutated residues are shown in red color $\left(\mathrm{A}_{14}, \mathrm{~F}_{42}\right.$, $\mathrm{F}_{144}$, and $\left.\mathrm{G}_{176}\right)$.

results in monomers with reduced activity, less than $\sim 30 \% .{ }^{18} \mathrm{~A}$ similar study of human Aqp4 showed a reduction in tetramerization when an intracellular loop was mutated. ${ }^{19}$ Hydrophobic interactions between monomers are not directly impacted by those mutations.

To date, there is little information available on the importance of intramembrane interactions on the stability of membrane proteins. In the context of individual transmembrane helices, building on the model of glycophorin $a{ }^{20}$ several factors have been highlighted including interactions between GxxxG motifs, ${ }^{21,22}$ burial of less hydrophobic surfaces, ${ }^{23,24}$ and polar clamps. ${ }^{25}$ Only recently has this work been extended to more extensive interfaces among the membrane proteins. Perhaps most importantly with the $\mathrm{ClC}$ protein from Escherichia coli, ${ }^{26,27}$ it has been demonstrated that tryptophan residues can severely disrupt dimer formation. ${ }^{27}$

In the work reported here, we have modified the hydrophobic surfaces within the lipid bilayer by mutating key interfacial residues, resulting in the destabilization of AqpZ tetramers. We characterize these AqpZ mutants in terms of structure, assembly, and function.

\section{RESULTS}

AqpZ is a hydrophobic membrane-embedded protein that forms a very stable tetrameric structure, ${ }^{28,29}$ with considerable buried surface area. On the basis of the amino acid sequence, ProtParam ${ }^{16}$ calculates a GRAVY index, a measure of hydrophobicity running from -4.5 for arginine to 4.5 for isoleucine, of 0.934 for the protein. The formation of the tetramer results in the burial of a large surface area that is calculated to be about $7000 \AA^{2}$ by PDBePISA. ${ }^{30}$ This represents a quarter of the protein surface area.

One known structural pattern for the stabilization of hydrophobic interfaces is a surface complementarity. In such a knobs into holes interface protrusion of amino acid side chains from one monomer into holes in the companion gives a complementary tight packing, ${ }^{31,32}$ much like the pieces of a puzzle. This arrangement prevents the destabilizing effects of cavities or solvent infiltration into the interface.

To destabilize the tetramer, we, therefore, examined the interface looking for target sites where knobs from one monomer were embedded in holes in the partner. On the basis of our observations, we targeted two sites in the center of the interface, which are highlighted in Figure 1.

At the first site, a knob on the first transmembrane helix formed by the residue $\mathrm{W}_{14}$ is located in a hole between the fourth and fifth transmembrane helices; one of the residues lining this hole is $\mathrm{G}_{144}$. To disrupt this interface, we constructed the mutants $\mathrm{W}_{14} \mathrm{~A}$ and $\mathrm{G}_{144} \mathrm{~F}$ that are expected to remove the knob and fill the hole, respectively, as can be readily appreciated for the steric clash illustrated in Figure 1B. We also constructed the double mutant $\mathrm{W}_{14} \mathrm{~A}-\mathrm{G}_{144} \mathrm{~F}$, hoping for some compensation between the two single mutations. The compensatory mutant chosen was with a phenylalanine rather than with a tryptophan as this appeared to be more easily accommodated when the structures were examined with PyMOL. ${ }^{33}$

At the second site, the knob was formed by the residue $I_{176}$ on helix 5 , and this was inserted in a groove between helices 1 and 2. One of the residues bordering this groove is $A_{42}$. To target this site, we again constructed three mutants $A_{42} F, I_{176} G$, and the double mutant $\mathrm{A}_{42} \mathrm{~F}-\mathrm{I}_{176} \mathrm{G}$. This set of mutations was again evaluated using PyMOL. ${ }^{33}$

As a starting point for our study, we decided to use the previously studied AqpZ- $\mathrm{C}_{20} \mathrm{~S}$ mutant. ${ }^{4}$ This protein is known to have a slightly destabilized tetrameric structure, and the presence of a single cysteine residue would facilitate experiments requiring labeling with maleimides.

Membrane protein topology and the orientation and location of transmembrane helices can be sensitive both to changes in protein sequence ${ }^{35,36}$ and to alterations in membrane composition. ${ }^{37} \mathrm{We}$, therefore, verified that the mutations we introduced did not modify the membrane insertion of AqpZ, Figure 2.

For this, we cloned N-terminal fragments of our starting strain AqpZ- $\mathrm{C}_{20} \mathrm{~S}$ and the various single and double mutants, ending after each transmembrane helix into the pKTop reporter plasmid. In the $\mathrm{C}_{20} \mathrm{~S}$ control strain, we note that the spots of cells containing constructs ending after helices 1,3 , and 5 of AqpZ are in blue color, indicating a periplasmic location, as expected. The spots of cells containing constructs ending after helices 4 and 6 are in red color, indicating the expected cytoplasmic topology. However, the spots containing the fusions ending after helix 2 are a deep purple color, strongly suggesting only partial insertion of helix 2 into the membrane, resulting in a mixed topology, and thus, a mixture of red and 


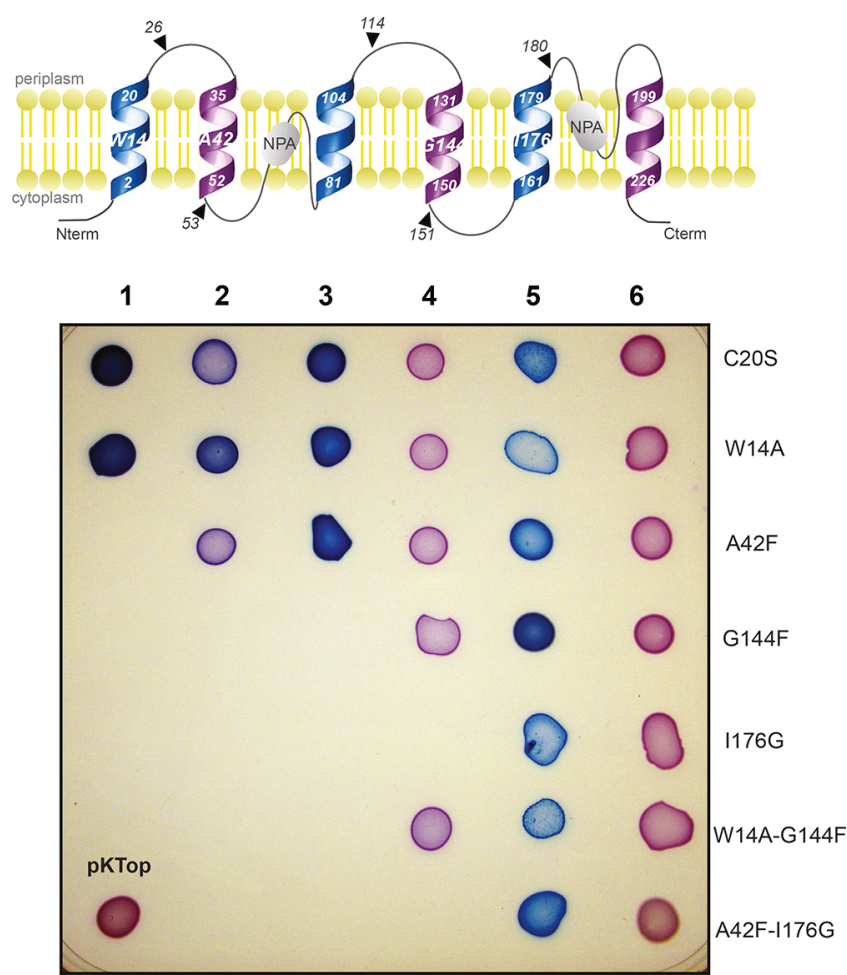

Figure 2. Effect of mutations on membrane insertion. (Top) Cartoon showing the expected topology of AqpZ. The color of the helices indicates the expected color of translational fusions ending after this helix using the pKTop system. The arrow heads indicate the last residues of the various fragments of AqpZ inserted into the pKTop reporter system. The numbers within the helices indicate their first and last residues, as determined by PyMOL. The positions of the mutations are indicated in various helices. The NPA (Asparagine Proline Alanine) labels indicate the incomplete helices that contain the conserved NPA motif. (Bottom) Spots $(7 \mu \mathrm{L})$ of overnight bacterial cultures diluted to an $\mathrm{OD}_{600 \mathrm{~nm}}$ of 0.5 were placed on indicator plates containing Red-Gal and BCIP and developed (see Materials and Methods). The numbers along the top edge indicate the last (Cterminal) helix in the construction, all constructions started from the $\mathrm{N}$-terminal of the protein. Blue color indicates a periplasmic location of the C-terminal of the construction inserted into the plasmid pKTop, whereas red color indicates a cytoplasmic location. The pKTop control shows the result with no insert into the plasmid. blue color was developed. This topology information is fully in agreement with the suggested importance of the interaction between helices 1 and 3 in the folding of the protein around the central pore. $^{38}$

Most of the different mutants result in very similar patterns of insertion. Importantly, all proteins show the expected blue and red color for the constructs containing helices 5 and 6 , respectively. This confirms that they are targeted to the membranes and oriented to give a cytoplasmic C-terminal domain.

Membrane protein overproduction can often be toxic for cells. To test the toxicity of our constructions, we grew a known amount of them on minimal media either with glucose or glycerol as a carbon source, Figure 3. As can be readily appreciated, strains expressing certain mutant AQPs are much less viable than others. The least viable cells were clearly those expressing the $\mathrm{A}_{42} \mathrm{~F}$ and $\mathrm{A}_{42} \mathrm{~F}-\mathrm{I}_{176} \mathrm{G}$ AqpZ variants, and the $\mathrm{G}_{144} \mathrm{~F}$ mutation also adversely affected cell viability. The situation is almost identical on plates containing the two different carbon sources. Glycerol is a nonfermentable substrate and thus can be used to test whether toxicity was linked to difficulty in maintaining a membrane potential. The microscopic examination of cultures expressing the different proteins did reveal that the cells had a tendency to filament, and filamentation was most prevalent in the least viable strains, namely, those expressing the $\mathrm{A}_{42} \mathrm{~F}, \mathrm{~A}_{42} \mathrm{~F}-\mathrm{I}_{176} \mathrm{G}$, and $\mathrm{G}_{144} \mathrm{~F}$ AqpZ variants.

2.1. Structural Analysis. To evaluate the effects of our modifications on the assembly of AqpZ, we determined the oligomerization state of the various modified proteins in several different environments.

In several studies, ${ }^{4,39}$ oligomerization of AqpZ has been followed after sodium dodecyl sulfate polyacrylamide gel electrophoresis (SDS-PAGE). Usually, the native AqpZ is sufficiently stable to remain tetrameric even after solubilization in SDS. As an initial test, we, therefore, expressed the proteins in E. coli cells and examined the synthesis and oligomeric state by SDS-PAGE and western blotting, Figure 4 .

In agreement with previous reports, ${ }^{4}$ AqpZ- $\mathrm{C}_{20} \mathrm{~S}$ showed both tetrameric and monomeric forms of AqpZ. In most mutants $\left(W_{14} A, G_{144} F, I_{176} G\right.$, and $\left.W_{14} A-G_{144} F\right)$, a single band corresponding to monomeric AqpZ was observed. This indicates that there is a reasonable level of protein production and that the tetrameric structure has, as expected, been destabilized. In the strains expressing the $\mathrm{A}_{42} \mathrm{~F}$ and $\mathrm{A}_{42} \mathrm{~F}-\mathrm{I}_{176} \mathrm{G}$
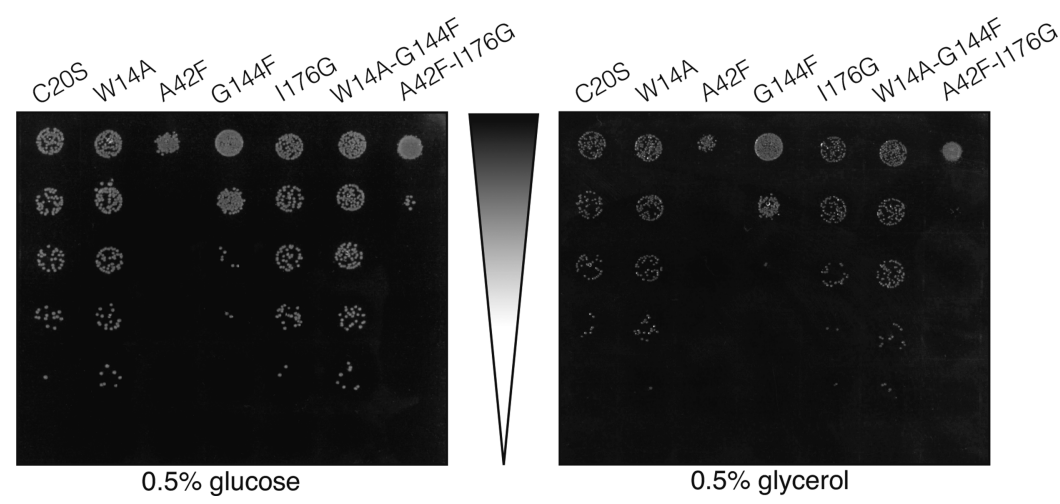

Figure 3. Toxicity of the different constructs. The cultures of E. coli were diluted overnight to an $\mathrm{OD}_{600}$ of 0.5 , and the serially diluted drops were spotted on M9 minimal media, supplemented either with $0.5 \%(\mathrm{w} / \mathrm{v})$ glucose (left) or with $0.5 \%(\mathrm{w} / \mathrm{v})$ glycerol (right), and were incubated overnight at $37^{\circ} \mathrm{C}$. 


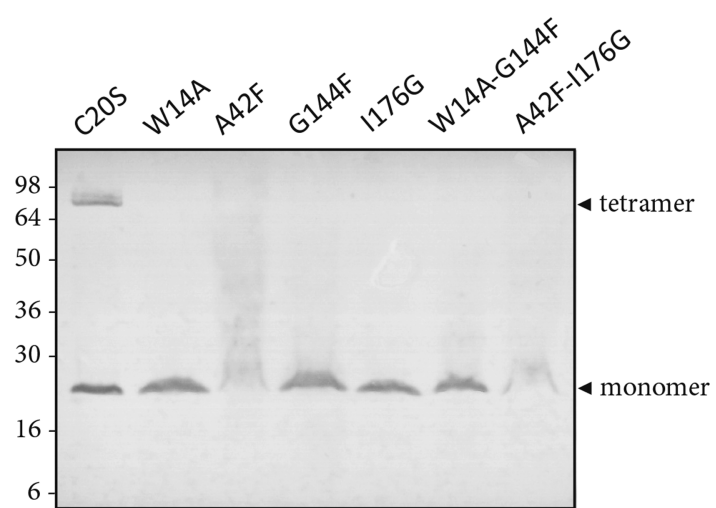

Figure 4. Western blot of an SDS-PAGE of E. coli cell pellets overexpressing the various AqpZ constructs. The same cell number (based on $\mathrm{OD}_{600 \mathrm{~nm}}$ ) was loaded in each lane. After electrophoresis and blotting, the N-terminal oligo-histidine tag is targeted by the first antibody (Qiagen), and then the blot was developed using alkalinephosphatase-coupled secondary antibody (Santa Cruz Biotechnology).

forms of the protein, a very little amount of protein was accumulated, only weak staining of the blot was observed, and no clear band was observed. Although protein production was limited in these strains, we did manage to purify the expressed protein, and after purification, they were found to be monomeric on SDS-PAGE, see Figure S1.

To gain further insight into the oligomeric state, the various different proteins were purified in the detergent dodecyl maltoside for the structural analysis. The oligomeric state of the purified proteins was investigated by both size exclusion chromatography and dynamic light scattering (DLS), Figure 5 , and the results are collected in Table 1 .

The different proteins showed various different sizes that were readily distinguished using size exclusion chromatography.
Table 1. Hydrodynamic Measurements of AqpZ Mutants Using Size Exclusion Chromatography and Dynamic Light Scattering

\begin{tabular}{llll}
\multicolumn{1}{c}{ mutant } & \multicolumn{1}{c}{$\begin{array}{c}\text { size exclusion } \\
\left(\mathrm{nm}^{3}\right)\end{array}$} & $\begin{array}{c}\text { light scattering size } \\
\left(\mathrm{nm}^{3}\right)\end{array}$ & polydispersity \\
$\mathrm{C}_{20} \mathrm{~S}$ & $169 \pm 27(n=4)$ & $267 \pm 51(n=3)$ & $0.29 \pm 0.05$ \\
$\mathrm{~W}_{14} \mathrm{~A}$ & $76 \pm 9(n=3)$ & $137 \pm 12(n=4)$ & $0.56 \pm 0.03$ \\
$\mathrm{~A}_{42} \mathrm{~F}$ & $87 \pm 9(n=2)$ & $203 \pm 66(n=6)$ & $0.55 \pm 0.06$ \\
$\mathrm{G}_{144} \mathrm{~F}$ & $214 \pm 11(n=3)$ & $271 \pm 8(n=6)$ & $0.31 \pm 0.02$ \\
$\mathrm{I}_{176} \mathrm{G}$ & $215 \pm 20(n=4)$ & $282 \pm 53(n=3)$ & $0.54 \pm 0.08$ \\
$\mathrm{~W}_{14} \mathrm{~A}-\mathrm{G}_{144} \mathrm{~F}$ & $174 \pm 38(n=2)$ & $243 \pm 37(n=3)$ & $0.79 \pm 0.05$ \\
$\mathrm{~A}_{42} \mathrm{~F}-\mathrm{I}_{176} \mathrm{G}$ & $87 \pm 8(n=2)$ & $524 \pm 35(n=3)$ & $0.26 \pm 0.08$ \\
\hline
\end{tabular}

The reference $\mathrm{C}_{20} \mathrm{~S}$ strain eluted at $K_{\mathrm{d}}$ of about 4.25. Some proteins eluted slightly earlier, for example, the $\mathrm{I}_{176} \mathrm{G}$ mutant shown in Figure 5. While others were clearly much smaller, as illustrated for the $\mathrm{W}_{14} \mathrm{~A}$ mutant. In light scattering, the various purified proteins gave relatively monodisperse peaks with characteristic size.

The volumes of the AqpZ monomer and tetramer, calculated from the crystallographic structure, are 32.2 and $129.8 \mathrm{~nm}^{3}$, respectively. These volumes are smaller than those of the protein-detergent complex present in the solution because hundreds of detergent molecules form a belt around the hydrophobic part of the membrane protein. ${ }^{40}$

Using size exclusion chromatography, the different AqpZ proteins fall into two groups. A first group with a volume of about $195 \mathrm{~nm}^{3}$ contains the $\mathrm{C}_{20} \mathrm{~S}, \mathrm{G}_{144} \mathrm{~F}, \mathrm{I}_{176} \mathrm{G}$, and $\mathrm{W}_{14} \mathrm{~A}-$ $\mathrm{G}_{144} \mathrm{~F}$ proteins. These proteins are presumably tetramers, in view of the observed size and the known structure of AqpZ. The small differences in size observed are possibly due to slight variations in the amount of detergent binding. A second group with a protein-detergent complex volume about half as large of
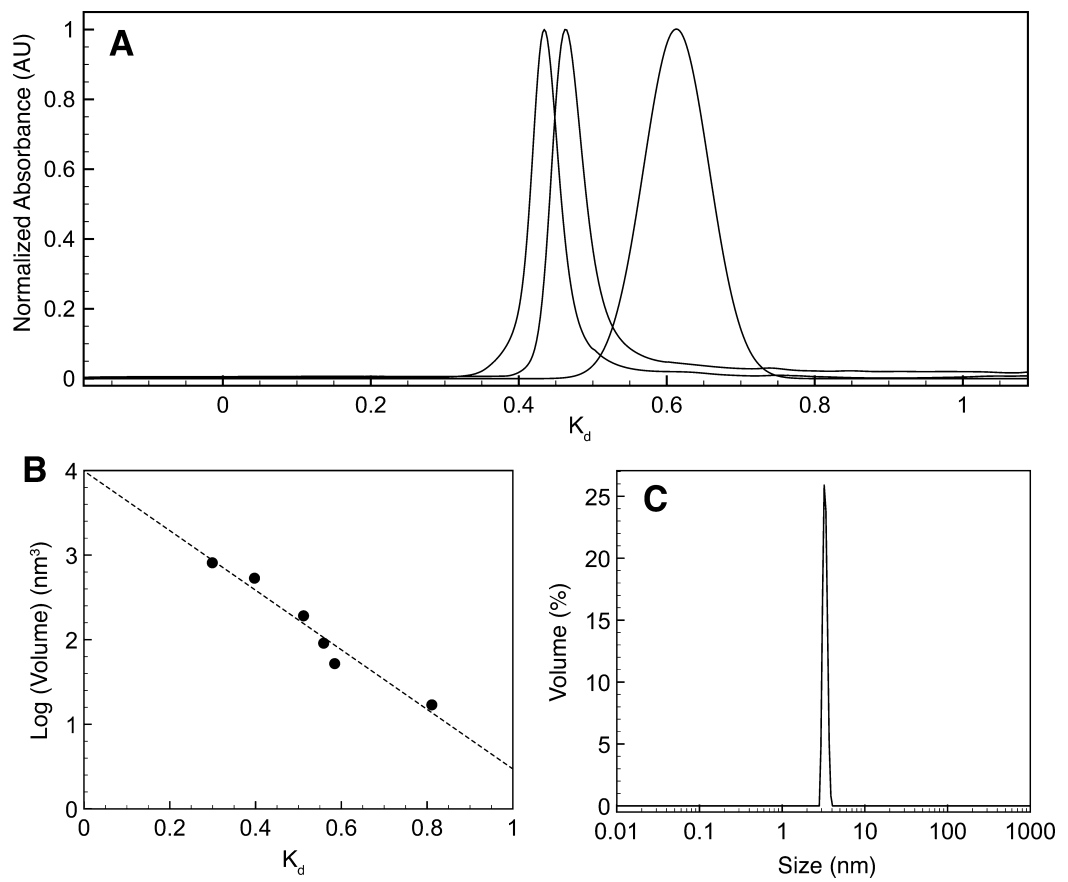

Figure 5. Size of purified proteins in dodecyl maltoside. (Panel A) Normalized size exclusion chromatography elution profiles for three different AqpZ variants: AqpZ- $\mathrm{I}_{176} \mathrm{G}$, the tetrameric control $\mathrm{C}_{20} \mathrm{~S}$, and the $\mathrm{W}_{14} \mathrm{~A}$ mutant (from left to right). (Panel B) Calibration curve used to estimate molecular volumes from size exclusion chromatography partition coefficients. (Panel C) Mass-weighted size distribution of purified AqpZ- $\mathrm{C}_{20} \mathrm{~S}$ obtained by DLS. 


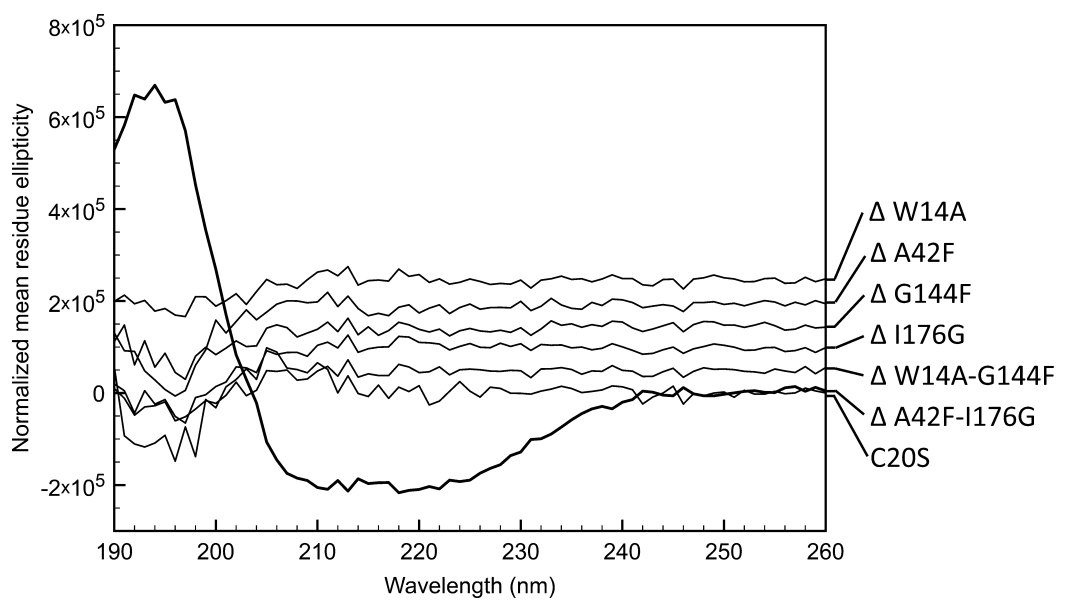

Figure 6. CD spectra of AqpZ proteins. The CD spectra of the purified proteins in dodecyl maltoside were measured and normalized to give the mean residue ellipticity. Shown is the spectrum obtained for the reference protein $\mathrm{C}_{20} \mathrm{~S}$, and difference spectra for each of the mutant proteins, vertically offset to aid visualization.

$82 \mathrm{~nm}^{3}$ contains the $\mathrm{W}_{14} \mathrm{~A}$ mutant and the two most toxic proteins $\mathrm{A}_{42} \mathrm{~F}$ and $\mathrm{A}_{42} \mathrm{~F}-\mathrm{I}_{176} \mathrm{G}$.

The results using DLS for the first group of proteins are entirely coherent with those obtained by using chromatography. All four proteins have similar sizes, although using this method of about $265 \mathrm{~nm}^{3}$. For the second group, the situation is more complex. The $\mathrm{W}_{14} \mathrm{~A}$ protein, as in the chromatographic measurements, shows a hydrodynamic size almost exactly half that of the first group of proteins. The last two proteins show less consistent behavior, possibly associated with the higher protein concentrations in these measurements. The $\mathrm{A}_{42} \mathrm{~F}$ mutant shows a size intermediate between that of the first group and $\mathrm{W}_{14} \mathrm{~A}$, whereas the $\mathrm{A}_{42} \mathrm{~F}-\mathrm{I}_{176} \mathrm{G}$ protein shows a much larger hydrodynamic volume.

Both methods, chromatography and DLS, have some potential difficulties with membrane proteins. As the detergent belt and the protein do not have uniform dielectric properties, we expect some systematic errors in the DLS analysis as a uniform diffusing particle is assumed. Furthermore, the presence of empty detergent micelles might influence the result, though these are expected to be smaller than the protein complexes and so contribute less signal. The measurement of size using chromatography is also made difficult by detergent binding to the column and standard proteins, and thus, systematic errors are expected. Thus, while the absolute sizes reported by these two methods are perhaps not exceedingly accurate, the relative measurements are probably reliable.

Altogether, these hydrodynamic measurements suggest that in dodecyl maltoside the protein-detergent complexes of the first group, $\mathrm{C}_{20} \mathrm{~S}, \mathrm{G}_{144} \mathrm{~F}, \mathrm{I}_{176} \mathrm{G}$, and $\mathrm{W}_{14} \mathrm{~A}-\mathrm{G}_{144} \mathrm{~F}$, probably contain tetrameric AqpZ proteins, with about equal masses of protein and detergent in agreement with previous studies on similar proteins in the same detergent. ${ }^{40}$ On the basis of the geometry of the protein-detergent complex proposed in previous studies, the proportion of protein in smaller complexes is reduced. Indeed if the geometric parameters obtained previously $^{40}$ are used to estimate the size of a detergent belt around a monomeric AQP, the total protein-detergent complex volume should be about half that of the tetramer. On the basis of these estimations, it seems reasonable to conclude that the smaller sizes observed in chromatography, and by DLS for the $\mathrm{W}_{14} \mathrm{~A}$ protein, correspond to monomeric AQPs, formed by destabilizing the hydrophobic interface.
Although the measured size might be consistent with a dimer, we believe in view of the monomeric state in the stronger detergent SDS and the detergent binding requirement that a monomer is a more reasonable explanation of our measurements. Clearly, the results from the two proteins, $\mathrm{A}_{42} \mathrm{~F}$ and $\mathrm{A}_{42} \mathrm{~F}-\mathrm{I}_{176} \mathrm{G}$, are not entirely satisfactory, with differences between the two methods used. This might be attributed to the difficulties in the production of the proteins or in our opinion problems with stability and aggregation linked to higher protein concentration and a less well-controlled protein-detergent ratio in DLS measurements.

Altogether, these measurements show that AqpZ in solution with the mild detergent dodecyl maltoside is tetrameric. The oligomeric structure is robust enough to accommodate the removal of the knob created by $\mathrm{I}_{176}$ and the steric clash created by the $\mathrm{G}_{144} \mathrm{~F}$ mutation. However, in this environment, the $\mathrm{W}_{14} \mathrm{~A}$ mutation, and probably the $\mathrm{A}_{42} \mathrm{~F}$ mutation as well, results in monomeric AQPs. Furthermore, the size estimations also suggest that the detergent belt is organized in a manner similar to that proposed for Aqp0, ${ }^{40}$ with almost as much detergent around a monomer as a tetramer.

To verify that changes in the quaternary structure were not linked to modifications in the secondary structure, we measured circular dichroism (CD) spectra of the various purified proteins (Figure 6).

The CD spectrum of AqpZ is typical of a largely $\alpha$ helical protein, with strong negative peaks at 208 and $222 \mathrm{~nm}$. Indeed, the secondary structure analysis using the $\mathrm{K} 2 \mathrm{D} 2{ }^{41}$ algorithm identified the same composition for all proteins, reporting $87.8 \% \alpha$ helices, $11.7 \%$ random coil, entirely consistent with the known AqpZ structures. However, not all spectra are identical, the height of the peak at $195 \mathrm{~nm}$ was slightly reduced in the various mutants, and this may suggest some modifications to the loops or be due to acquisition problems at these low wavelengths. The largest difference spectrum is that for the double mutant $\mathrm{A}_{42} \mathrm{~F}-\mathrm{I}_{176} \mathrm{G}$ that gives a less negative signal at $208 \mathrm{~nm}$, resulting in a modified ratio of the minima, $\phi_{222} / \phi_{208}$ of 0.97 as opposed to 1.13 found for the other proteins. This change in $C D$ spectrum might be attributed to an increase in scattering, flattening, changes in local dielectric constant, ${ }^{42}$ or a reduction in interhelical coupling. ${ }^{43}$ Surprisingly, this change was not reflected by an increase in the $\alpha$-helical content as predicted by K2D2, as might have been expected. ${ }^{43}$ 
These measurements show that the secondary structure of the proteins, as determined by $\mathrm{K} 2 \mathrm{D} 2$, is unperturbed by the mutations, and there is no apparent coupling between the secondary structure and the formation of tetramers for AqpZ, even in the detergent solution.

Unfortunately, the activity of AQPs cannot be measured in the detergent solution; thus to verify the effects of destabilizing mutations on activity, we reconstituted the proteins into proteoliposomes. The activity was then measured by monitoring light scattering after hyperosmotic shock, Figure 7. However, we were unable to prepare sufficient purified protein to permit activity measurements on the $\mathrm{A}_{42} \mathrm{~F}$ and $\mathrm{A}_{42} \mathrm{~F}-\mathrm{I}_{176} \mathrm{G}$ proteins.

When reconstituted in liposomes, made from E. coli total lipid extract, light scattering changes can be observed owing to vesicle shrinkage because of the water moving out of the vesicles, following a decrease in the external osmotic pressure. The observed changes can be fitted to a single exponential, Figure 7, panel A. The characteristic time we observed for vesicle swelling in the absence of AqpZ was about $0.3 \mathrm{~s}$. When AqpZ $\mathrm{C}_{20} \mathrm{~S}$ is introduced into the liposomes at a protein/lipid ratio of 0.001 , in panel $\mathrm{B}$ diamonds, the permeability increased and the characteristic time was reduced to about $0.1 \mathrm{~s}$, increasing the protein concentration 10-fold; in panel B filled triangles, the rate of scattering changes increased to below the time resolution of our experimental setup. These results are entirely consistent with those obtained previously for this protein. ${ }^{4}$ We measured kinetics for proteoliposomes containing the different proteins, panel $\mathrm{C}$, to measure the water conduction activity of each protein. The curves obtained with the $\mathrm{C}_{20} \mathrm{~S}, \mathrm{G}_{144} \mathrm{~F}$, and $\mathrm{W}_{14} \mathrm{~A}-\mathrm{G}_{144} \mathrm{~F}$ proteins reconstituted into liposomes were very similar; however, a reduced permeability was observed when the monomeric $\mathrm{W}_{14} \mathrm{~A}$ mutant was incorporated into liposomes.

The characteristic time for proteoliposome shrinkage depends on the surface-to-volume ratio of the liposomes and the permeability of the membrane. We estimated the permeability of the membrane from single exponential fits to the light scattering data and the average size of the liposomes measured by DLS. From the change in this value and the protein density, the single channel permeabilities can in turn be estimated. These values are shown in Table 2 . It is immediately clear from these measurements that the three tetrameric proteins tested show high permeability between 9.5 and $11.3 \times$ $10^{-14} \mathrm{~cm}^{3} \mathrm{~s}^{-1}$. These values are in complete agreement with previous observations. ${ }^{4}$ The monomeric $\mathrm{W}_{14} \mathrm{~A}$ mutant has a much smaller permeability by only about $4.1 \times 10^{-14} \mathrm{~cm}^{3} \mathrm{~s}^{-1}$.

It is particularly interesting to note that the reduced membrane permeability in the monomeric $\mathrm{W}_{14} \mathrm{~A}$ mutant is almost completely restored in the tetrameric $\mathrm{W}_{14} \mathrm{~A}-\mathrm{G}_{144} \mathrm{~F}$ double mutant.

\section{DISCUSSION}

AQPs are a family of tetrameric membrane proteins; however, the functional role of this oligomerization and the forces driving the assembly are not clear. In the present work, we have modified the membrane-embedded interfaces of the AqpZ protein, making mutations designed to cause steric clashes and the formation of holes.

In studies of GlpF folding, it has been suggested that the protein folds in two subdomains containing helices 1 to 3 and 4 to $6{ }^{44}$ Within each subdomain, it is proposed that interactions between the parallel helices ( 1 and 3 or 4 and 6) are crucial for
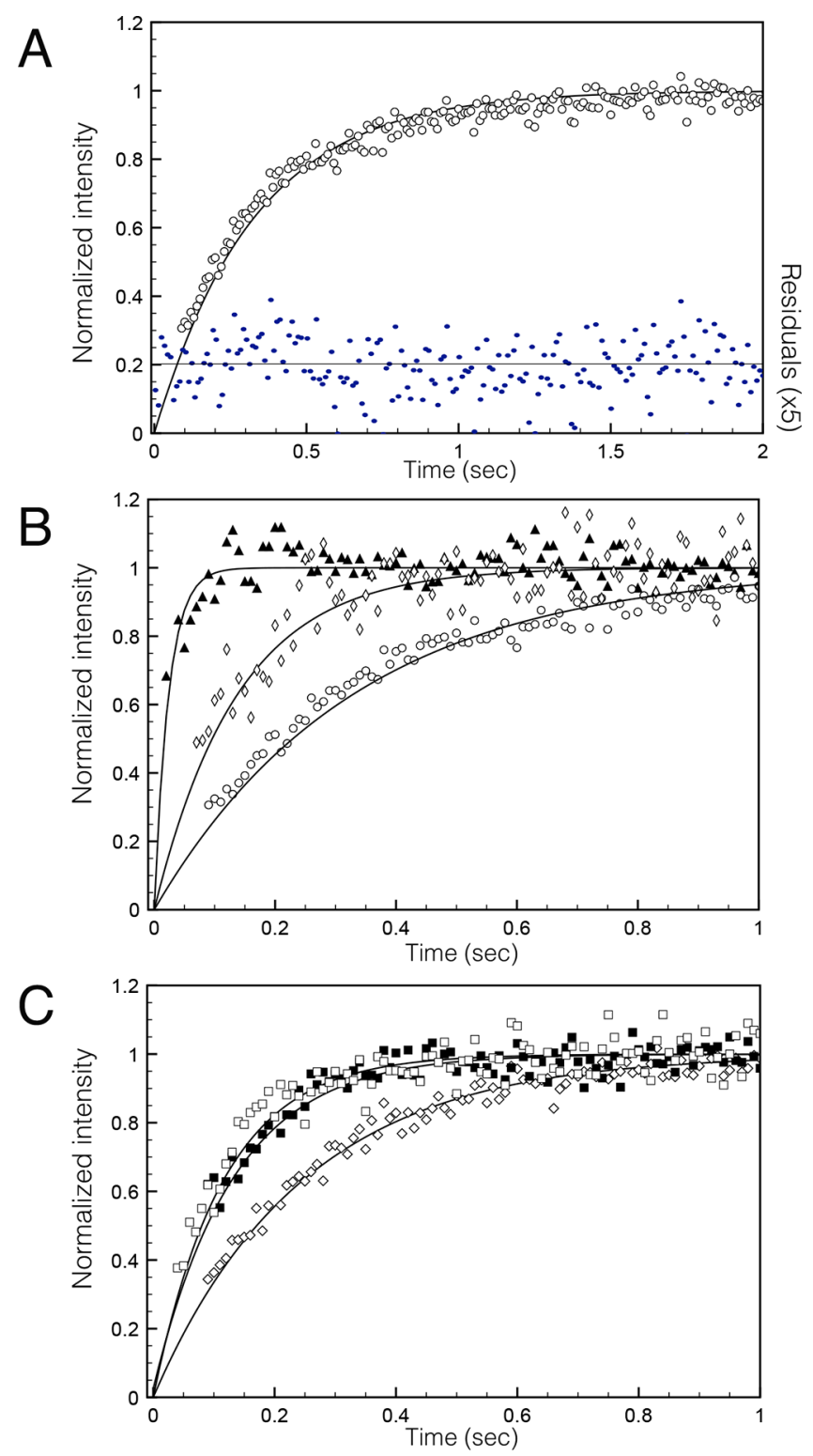

Figure 7. Measurements of water permeation in proteoliposomes. Proteoliposomes were submitted to an abrupt hyperosmotic shock, followed by light scattering changes. (Panel A) Liposomes (circles) containing no protein and a single exponential fit to the data (line). Residuals are plotted in the bottom on an expanded scale. (Panel B) Tetrameric AqpZ- $\mathrm{C}_{20} \mathrm{~S}$ was reconstituted at different protein-to-lipid ratios, and scattering changes were measured. Shown are data from vesicles with ratios of 0.010 (filled triangles), 0.001 (open diamonds), and 0.000 (open squares). (Panel C) Kinetics measured for proteoliposomes reconstituted with AqpZ-W $\mathrm{W}_{14} \mathrm{~A}$ (open diamonds), $\mathrm{G}_{144} \mathrm{~F}$ (filled squares), and $\mathrm{W}_{14} \mathrm{~A}-\mathrm{G}_{144} \mathrm{~F}$ (open squares) proteins all at a protein/lipid ratio of 0.001 .

Table 2. Membrane Permeability ${ }^{a}$

\begin{tabular}{lc}
\multicolumn{1}{c}{ mutant } & channel permeability $\left(\mathrm{cm}^{3} \mathrm{~s}^{-1}\right)$ \\
$\mathrm{C}_{20} \mathrm{~S}$ & $11.3 \pm 2.3 \times 10^{-14}(n=3)$ \\
$\mathrm{W}_{14} \mathrm{~A}$ & $4.1 \pm 2.0 \times 10^{-14}(n=2)$ \\
$\mathrm{G}_{144} \mathrm{~F}$ & $11.1 \pm 2.9 \times 10^{-14}(n=2)$ \\
$\mathrm{W}_{14} \mathrm{~A}-\mathrm{G}_{144} \mathrm{~F}$ & $9.5 \pm 1.5 \times 10^{-14}(n=2)$
\end{tabular}

${ }^{a}$ Permeability was calculated from the exponential fits to scattering changes (Figure 7) in proteoliposomes containing proteins at a protein/lipid ratio of 0.001 . 
the folding of the respective subdomains, whereas the antiparallel interaction between helices 2 and 5 connects the two subdomains. This is slightly different from the model proposed for Aqp $1^{45}$ in which the antiparallel interaction between helices 2 and 5 drives, in a concerted rearrangement, the insertion of helices 2 and 4 and the reorientation of helix 3 . Our protein topology experiments allow us to follow the assembly of AqpZ. The constructs containing helices 1-2 appear to show a mixed topology, whereas those containing helices 1-3 show a single "correct" topology. The constructs containing helices 1-4 also appear to show a "correct" topology. These observations suggest that during the folding of AqpZ, similar to the model proposed for $\mathrm{GlpF}^{44}$ the parallel interaction between helices 1 and 3 stabilizes insertion of helix 2. Examining the mutants, this insertion may also be stabilized by tryptophan at position 14 and phenylalanine at position 42 . Presumably, this second effect is due to the increased hydrophobicity of phenylalanine compared to that of alanine. However, the interaction between helices 4 and 6 appears less important for the insertion of helix 5. Furthermore, unlike Aqp $1,{ }^{45}$ the interaction between helices 2 and 5 does not appear to be required for the correct topology. These observations on multiple members of the same family would tend to suggest that the two-stage model for membrane protein folding ${ }^{46,47}$ is over simplistic because membrane insertion can be linked to assembly and furthermore that whereas structure is conserved the folding pathway is not.

The first role proposed for the tetrameric nature of AQPs was as a requirement for stable integration into the bilayer. ${ }^{48}$ However, calculations of the free energy transfer for the various transmembrane helices of GlpF and other members of the family suggest that this is not the case. ${ }^{38}$ Furthermore, several mutated monomeric AQPs have been studied: for example, a human Aqp4 with a $\mathrm{V}_{71} \mathrm{M}$ mutation in the first incomplete helix, ${ }^{19}$ or GlpF with an $\mathrm{E}_{43} \mathrm{~A}^{18}$ which appears to insert correctly in the membrane. In agreement with these previous studies, our monomeric $\mathrm{W}_{14} \mathrm{~A}$ mutant also appears to insert normally into the membrane. Thus, in partial accord with the two-stage model for membrane protein folding, ${ }^{46,47}$ there does not appear to be a link between insertion and oligomerization.

Several previous studies have examined the link between the tetramer formation and the permeability of AQPs. In Aqp4, the $\mathrm{V}_{71} \mathrm{M}$ mutation decreased the oligomer assembly, but the resulting monomer has water permeability comparable to WTAqp 4. ${ }^{19}$ By contrast, in Aqp2, the $\mathrm{R}_{187} \mathrm{C}$ mutation results in inactive monomers. ${ }^{49}$ Similarly, the monomeric GlpF protein with the $\mathrm{E}_{43} \mathrm{~A}$ mutation ${ }^{18}$ shows reduced activity. In this study, we again show a link between oligomerization and activity for an AQP. Perhaps most convincingly, while the $\mathrm{W}_{14} \mathrm{~A}$ mutant is both monomeric and has reduced activity, the oligomeric state and transport activity are both restored by the compensating second-site mutation $\mathrm{G}_{144} \mathrm{~F}$.

It is not entirely clear why there should be a link between the oligomeric state and permeability; however, it is noteworthy that in several different proteins of the family, in different laboratories, with mutations in different parts of the protein this association has been found. It seems unlikely that there are major changes in the tertiary structure between monomeric and tetrameric proteins, and it is clear from the CD spectra that there are minimal modifications in the secondary and suprasecondary structure. Thus, changes are likely restricted to subtle structural changes or changes in dynamics, resulting in a transition between an open and a closed state. ${ }^{50}$ One possibility is that the monomer is sensitive to the membrane lateral pressure, resulting in conversion to a closed state, whereas the tetramer is protected from such deformation. For example, the $90^{\circ}$ angle at the $C_{4}$ symmetry axis might have a tendency to change slightly in a monomeric protein favoring a closed state, whereas in the tetramer such a deformation is hindered.

It is remarkable that of the different point mutations we have made, designed to disrupt the tetrameric structure, we appear to have been successful in two out of four attempts $\mathrm{W}_{14} \mathrm{~A}$ and $\mathrm{A}_{42} \mathrm{~F}$ and failed with the other two $\mathrm{G}_{144} \mathrm{~F}$ and $\mathrm{I}_{176} \mathrm{G}$.

The $\mathrm{W}_{14}$ residue is located in the middle of an "aromatic tetrad", formed by $\mathrm{F}_{10}, \mathrm{~F}_{13}, \mathrm{~W}_{14}$, and $\mathrm{F}_{17}$. We hypothesize that the interactions among the remaining three aromatic residues reduce the possibility for reorganization of the structure, and thus, the mutation results in a large hole in the interface. This hole is very hydrophobic and able to strongly bind lipid, or detergent, molecules, and these hinder the formation of the protein-protein contacts in the tetramer. However, in the presence of the $\mathrm{G}_{144} \mathrm{~F}$ mutation, the lipids can be displaced by the phenylalanyl residue. The $\mathrm{A}_{42} \mathrm{~F}$ mutation appears to introduce a steric clash that is sufficiently severe to disrupt the interface. By contrast, we must assume that for the other point mutations the interface is able to reorganize and thus limit the steric clash or the size of the hole in the structure.

It is worth pointing out that the energetics of interface disruption in a lipid environment is expected to be rather different from that observed for soluble proteins. Water offers a small molecule isotropic environment. Thus, in an aqueous environment, small interfacial holes can be readily filled by a water molecule, ${ }^{51}$ causing a minimal energy penalty. Equally steric clashes can lead to rearrangements, allowing a few water molecules to infiltrate the interface. ${ }^{52}$ In the case of a phospholipid environment, the situation is rather different. The environment is strongly anisotropic. The entry of water into the hydrophobic core of the membrane is energetically unfavorable, but the large anisotropic solvent molecules cannot fill interfacial holes without seriously disrupting the interface. In the same way, relieving steric clashes by allowing solvent infiltration into the interface is geometrically more complex because of the large size and specific shape of the solvent molecules. This reasoning suggests that the lipid-embedded interfaces may be more fragile than the interfaces in aqueous environments because of the reduced possibility of solvent infiltration. In particular, we suspect that part of the difference in the behavior of the $\mathrm{W}_{14} \mathrm{~A}$ and $\mathrm{I}_{176} \mathrm{G}$ mutants is due to the ease with which the lipids can solvate the monomer surface. The remains of the aromatic tetrad provide a relatively good anchor for lipid molecules compared with the smaller holes left by the removal of the isoleucine side chain. These observations are entirely coherent with those on the $\mathrm{ClC}$ transporter, in which a single I $\rightarrow \mathrm{W}$ mutation can lead to the destabilization of almost $10 \mathrm{~kJ} \mathrm{~mol}^{-1}$. 27

We have previously proposed ${ }^{53}$ that the membrane protein assembly into oligomers is in part driven by lipophobic interactions, resulting from the perturbation by the protein of lipid-lipid interactions. The mutants we describe here offer an interesting system to study the influence of lipid-protein interactions on the membrane protein assembly. Intriguingly, none of the mutations showed evidence of a dynamic monomer-tetramer equilibrium, for example, by the presence of multiple peaks or unexpectedly wide peaks in light scattering or gel filtration. Perhaps this indicates a strong sensitivity of association constant to small changes at the interface. In this 
Table 3. Oligonucleotides Used for Site-Directed Mutagenesis

\begin{tabular}{ll} 
name & \multicolumn{1}{c}{ sequence } \\
$\mathrm{W}_{14} \mathrm{~A}$ & 5'-CTGAATGTTTTGGTACTTTCGCGCTTGTTTTTGGTGGCTCTGG-3' $^{\prime}$ \\
$\mathrm{A}_{42} \mathrm{~F}$ & 5'-CATTGGTTTTGCCGGCGTGGCGTTGTTCTTCGGTCTGACCGTTCTGACGATGG-3' \\
$\mathrm{G}_{144} \mathrm{~F}$ & 5'-TTGAACTGGTATTGAGTGCATTTTTCCTGTTGGTGATCCACGG-3' \\
$\mathrm{I}_{176} \mathrm{G}$ & 5'-CCTTAACCCTGATTCACTTAGGTAGTATTCCGGTGACTAACAC-3'
\end{tabular}

Table 4. Oligonucleotides Used for Inserting Fragments of AqpZ into pKTop ${ }^{a}$

\begin{tabular}{ll} 
name & \multicolumn{1}{c}{ sequence } \\
H0 & 5'-TCTAAGCTTAATGTTCAGAAAATTAGCAGCTGAATGTTTT-3' \\
H1-1 & 3'-TAGGTACCCCTAATTCCGGGAAGCCTG-5' \\
H1-2 & 3'-AGATCTAGATCGTTAAAATGACCACCAGAAATATGACCAA-5' \\
H1-3 & 3'-ATGGTACCCCATAACCGTTAGAAGCAAAA-5' \\
H1-4 & 3'-TCTTCTAGAATCGCGAATTTGTCGGTTGCG-5' \\
H1-5 & 3'-AGATCTAGAACCGGGTTAACAGAAGTGTTAGTCAC-5' \\
H1-6 & 3'-AGATCTAGATAATCACGCTTTTCCAGCAGGG-5'
\end{tabular}

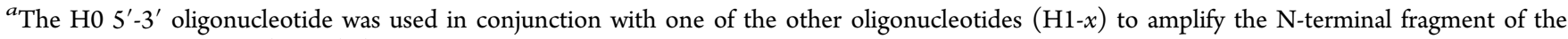
gene covering transmembrane helices 1 to $x$

context, the inability of the $\mathrm{I}_{176} \mathrm{G}$ and $\mathrm{G}_{144} \mathrm{~F}$ mutations to disrupt the tetramer would indicate that, despite similar volume changes at the interface to the other mutations, they can easily accommodate in the protein structure or provide less easily solvated surfaces.

\section{MATERIALS AND METHODS}

4.1. Site-Directed Mutagenesis. Protein synthesis was driven from plasmids derived from the previously described pTrc-10His-AqpZ- $\mathrm{C}_{20} \mathrm{~S}$ plasmid. ${ }^{4}$ Mutations were introduced using the megaprimer method, ${ }^{54}$ using the oligonucleotides in Table 3. DNA sequences were verified by sequencing (GATC Biotech, Mulhouse).

4.2. Protein Production. Competent E. coli strain W3110 cells were freshly transformed with the appropriate plasmid and were grown on Luria broth plates supplemented with a $25 \mu \mathrm{g} /$ $\mathrm{mL}$ ampicillin at $37{ }^{\circ} \mathrm{C}$. A single colony was selected, and a culture was grown overnight in Luria broth containing $25 \mu \mathrm{g} /$ $\mathrm{mL}$ ampicillin as antibiotic and $0.4 \%$ glucose at $37{ }^{\circ} \mathrm{C}$. This culture was diluted 100 -fold into a fresh broth supplemented with $0.4 \%$ glucose and was grown to an optical density (OD) at $600 \mathrm{~nm}$ of at least 1.2. To induce aqpZ gene expression, $1 \mathrm{mM}$ isopropyl $\beta$-D-1-thio-galacto-pyranoside (IPTG) was then added, and the culture was incubated for a further $3 \mathrm{~h}$ at $30^{\circ} \mathrm{C}$.

Cells were harvested by centrifugation, $20 \mathrm{~min}$ at $9000 \mathrm{~g}$, and resuspended in $1 / 200$ th of the original culture volume of icecold lysis buffer containing $100 \mathrm{mM} \mathrm{K}_{2} \mathrm{HPO}_{4}, \mathrm{pH} 7.0 ; 1 \mathrm{mM}$ $\mathrm{MgSO}_{4} ; 1 \mathrm{mM}$ phenylmethylsulfonyl fluoride (PMSF); and 0.1 $\mathrm{mg} / \mathrm{mL}$ deoxyribonuclease 1 . Cells were broken by sonication, 3 cycles of $1 \mathrm{~min}$ each followed by $1 \mathrm{~min}$ at $4{ }^{\circ} \mathrm{C}$. Unbroken cells and debris were separated from the cell lysate by centrifugation, $30 \mathrm{~min}$ at $10000 \mathrm{~g}$. Membrane fragments in the supernatant were collected by centrifugation, $60 \mathrm{~min}$ at 140 $000 \mathrm{~g}$, and then the membrane pellet was solubilized overnight at $4{ }^{\circ} \mathrm{C}$ in solubilization buffer: $100 \mathrm{mM} \mathrm{K}_{2} \mathrm{HPO}_{4}, \mathrm{pH} 8.0 ; 200$ $\mathrm{mM} \mathrm{NaCl}$; and $3 \% n$-dodecyl- $\beta$-D-maltoside (DDM) (SigmaAldrich). The insoluble material was removed by centrifugation, $60 \mathrm{~min}$ at $140000 \mathrm{~g}$.

4.3. Protein Purification. AQPs were purified from the detergent solubilized supernatant by affinity using a His-Trap HP column (GE Healthcare) attached to an ÄKTA system (GE Healthcare). The column was equilibrated with 10 column volumes $(\mathrm{CV})$ of wash buffer: $100 \mathrm{mM} \mathrm{K}_{2} \mathrm{HPO}_{4}, \mathrm{pH} 8.0 ; 200$ $\mathrm{mM} \mathrm{NaCl}$; $0.05 \%$ DDM; and $50 \mathrm{mM}$ imidazole. The solubilized proteins were loaded onto the column, and the column was then washed with $5 \mathrm{CV}$ of wash buffer to remove nonspecifically bound material. Elution was performed with a $10 \mathrm{CV}$ gradient from 0 to $100 \%$ elution buffer: $100 \mathrm{mM}$ $\mathrm{K}_{2} \mathrm{HPO}_{4}, \mathrm{pH} 8.0 ; 200 \mathrm{mM} \mathrm{NaCl} ; 0.05 \%$ DDM; and $500 \mathrm{mM}$ imidazole. Fractions containing AqpZ were pooled and washed in Microsep columns (VWR, 10k cutoff) with $5 \mathrm{CV}$ of conservation buffer $\left(\mathrm{NaCl} 137 \mathrm{mM}, \mathrm{KCl} 2.7 \mathrm{mM}, \mathrm{K}_{2} \mathrm{HPO}_{4} 1.4\right.$ $\mathrm{mM}, \mathrm{Na}_{2} \mathrm{HPO}_{4} 16.29 \mathrm{mM}, 0.05 \%$ DDM, pH 8.0).

4.4. Size Exclusion Chromatography. The hydrodynamic sizes of protein-detergent complexes can be estimated by using size exclusion chromatography on appropriate columns. Pure AqpZ (1 mg) was injected in 500 $\mu \mathrm{L}$ on a Superose $610 / 300 \mathrm{GL}$ (GE Healthcare) column previously equilibrated with elution buffer $(\mathrm{NaCl} 200 \mathrm{mM}, \mathrm{KCl}$ $2.7 \mathrm{mM}, \mathrm{K}_{2} \mathrm{HPO}_{4} 1.4 \mathrm{mM}, \mathrm{Na}_{2} \mathrm{HPO}_{4} 16.29 \mathrm{mM}, 0.05 \%$ DDM, $\mathrm{pH}$ 8.0). The column was developed with the same buffer.

To determine the volumes of protein-detergent complexes, the Superose $610 / 300$ GL column was calibrated, using the Gel Filtration Calibration Kit HMW (GE Healthcare) supplemented with lysozyme $(14 \mathrm{kDa})$ and Atto532 in elution buffer. The partition coefficient, $K_{\mathrm{d}}$, for each protein was calculated from $K_{\mathrm{d}}=\left(V_{\mathrm{m}}-V_{\mathrm{o}}\right) /\left(V_{\mathrm{t}}-V_{\mathrm{o}}\right)$, where $V_{\mathrm{o}}$ is the void volume determined with blue dextran, $V_{\mathrm{t}}$ is the geometric bed volume determined with Atto532, and $V_{\mathrm{m}}$ is the elution volume at the peak monitored by absorbance at $280 \mathrm{~nm}$. The volumes of the proteins in the calibration kit were estimated by assuming a protein density of $1.212 \times 10^{-3} \mathrm{~nm}^{3} \mathrm{Da}^{-1}$.

4.5. Dynamic Light Scattering. The hydrodynamic sizes of protein-detergent complexes and liposomes were also estimated by DLS. For protein samples, a concentration of about $1 \mathrm{mg} / \mathrm{mL}$ was used.

For this, we used a Zetasizer Nano-series Nano-S instrument (Malvern). Samples were briefly equilibrated for $300 \mathrm{~s}$ at $25^{\circ} \mathrm{C}$. Default settings in the software were used for optimizing measurement settings and duration. The multiple narrow mode analysis of the correlation data was used to obtain volumebased particle size distributions using the manufacturer's software. 
4.6. Topology Evaluation. In vivo orientation of membrane proteins can be examined using translational fusions with the proteins $\beta$-galactosidase and alkaline phosphatase because alkaline phosphatase is only active in the periplasm, whereas $\beta$-galactosidase requires cytoplasmic localization for activity.

To control the correct insertion of the $\alpha$ helices of the mutant AqpZ in the membrane, we amplified the appropriate gene fragment by polymerase chain reaction (PCR) using the oligonucleotides shown in Table 4, which was digested with HindIII and $\mathrm{XbaI}$ before overnight ligation at $16{ }^{\circ} \mathrm{C}$ into the pKTop plasmid ${ }^{56}$ previously digested with the same enzymes. The ligation mixture was then transformed into competent $E$. coli $\mathrm{DH} 5 \alpha$ cells.

A freshly transformed colony was selected, and the cells were grown overnight, diluted to an $\mathrm{OD}_{600 \mathrm{~nm}}$ of 0.5 , and $7 \mu \mathrm{L}$ was spotted onto dual-indicator plates. These plates contain Luria broth agar supplemented with the indicators $80 \mu \mathrm{g} / \mathrm{mL}$ disodium 5-bromo-4-chloro-3-indolyl phosphate (BCIP) and $100 \mu \mathrm{g} / \mathrm{mL}$ 6-chloro-3-indolyl- $\beta$-D-galactoside (Red-Gal), the inducer $1 \mathrm{mM}$ IPTG, and the antibiotic $50 \mu \mathrm{g} / \mathrm{mL}$ kanamycin. Plates were developed overnight at $37{ }^{\circ} \mathrm{C}$.

4.7. Toxicity Assay. As membrane protein production is toxic, we evaluated the effects of AqpZ synthesis on cell growth. A freshly transformed colony containing the appropriate plasmid in the W3110 strain was selected, and the cells were grown overnight, diluted to an $\mathrm{OD}_{600 \mathrm{~nm}}$ of 0.5 . A $50 \%$ serial dilution was then prepared. Samples of $7 \mu \mathrm{L}$ were spotted onto M9 minimal media agar plates, supplemented with either $0.5 \%$ $(\mathrm{w} / \mathrm{v})$ glucose or $0.5 \%(\mathrm{w} / \mathrm{v})$ glycerol, and the cells were grown overnight at $37{ }^{\circ} \mathrm{C}$ before scoring.

4.8. Circular Dichroism. UV CD spectra were acquired on a Jasco J-815 CD spectrometer using the same $0.1 \mathrm{~cm}$ cuvette for all purified AqpZ mutants. Proteins were dialyzed for $2 \mathrm{~h}$ at $4{ }^{\circ} \mathrm{C}$ against 1000 volumes of $0.05 \%(\mathrm{w} / \mathrm{v})$ DDM to reduce sodium absorption. The spectra were acquired with a resolution of $0.2 \mathrm{~nm}$ with an integration time of $1 \mathrm{~s}$, and 20 scans were accumulated, with baseline being set to zero from 245 to 260 $\mathrm{nm}$. To compare spectra from different mutants, the ellipticity was converted from millidegree (mdeg) to mean residue ellipticity $[\phi]_{\mathrm{MR}}$ using the formula $[\phi]_{\mathrm{MR}}=\left(M_{\mathrm{MRW}} \times \phi\right) /(10 \times$ $l \times c)$, where $M_{\mathrm{MRW}}$ is the average amino acid residue weight = $110 \mathrm{Da}, \phi$ is the measured ellipticity in mdeg, $l$ is the path length $=0.1 \mathrm{~cm}$, and $c$ is the protein concentration in $\mathrm{mg} / \mathrm{mL}$. Protein concentrations between 0.5 and $3.0 \mathrm{mg} / \mathrm{mL}$ were used in these experiments. The secondary structure composition was calculated by a K2D2 algorithm. ${ }^{41}$

4.9. Proteoliposome Reconstitution. Purified AqpZ$\mathrm{C}_{20} \mathrm{~S}$ and AqpZ-W $\mathrm{W}_{14} \mathrm{~A}$ were reconstituted into proteoliposomes essentially as previously described. ${ }^{4}$ Briefly, $10 \mathrm{mg}$ of $E$. coli total lipid extract (Avanti Polar Lipids, Inc) was resuspended in 1:2 methanol/chloroform solution, dried under nitrogen flow followed by $30 \mathrm{~min}$ under vacuum. Lipids were vortexed with MOPS (3-(N-morpholino)propanesulfonic acid) $100 \mathrm{mM}$, NMDG ( $N$-methyl-D-glucamine) $50 \mathrm{mM}$, pH 7.5 buffer for resuspension. Then, $n$-octyl- $\beta$-D-glucopyranoside was added, and then the OD was measured at $280 \mathrm{~nm}$ until a clear suspension was obtained. The lipid-detergent mixture was equilibrated overnight at room temperature. Purified AqpZ was then added to give a $1: 100$ or $1: 1000$ protein/lipid ratio $(w / w)$, and the mixture was incubated for $2 \mathrm{~h}$ at room temperature. Reconstitution was performed by dialysis in 20k MINI Dialysis Devices (Thermo Scientific) against 100 volumes of a MOPS
$100 \mathrm{mM}$, NMDG $50 \mathrm{mM}$ buffer for $72 \mathrm{~h}$ at room temperature. Buffer was changed after $48 \mathrm{~h}$. After dialysis, the proteoliposomes were passed 11 times through an extruder (Avanti Polar Lipids Inc.) fitted with a $200 \mathrm{~nm}$ polycarbonate membrane to reduce size heterogeneity. Liposome size was evaluated by DLS. While protein recovery was close to $100 \%$, it is not entirely clear how homogeneous the protein/lipid ratio is.

4.10. Kinetic Measurements. The osmotic behavior of proteoliposomes was analyzed by following the light scattering at $600 \mathrm{~nm}$ with a Fluorolog-3 spectrofluorimeter (Jobin-Yvon, Lonjumeau) after rapidly mixing equal volumes of proteoliposomes $(100 \mu \mathrm{L}$ each $)$ and hyperosmolar buffer in a stoppedflow apparatus accessory SFA-20 Hi-Tech Scientific (TgK Scientific, United Kingdom). The liposomes were prepared in $100 \mathrm{mM}$ MOPS, $50 \mathrm{mM}$ NMDG, pH 7.5 hyperosmolar buffer, containing in addition $157 \mathrm{mM}$ sucrose.

Proteoliposomes permeabilities were calculated with the following equation

$$
P_{\mathrm{f}}=\frac{k \times r}{3 \times v_{\mathrm{w}} \times \Delta_{\mathrm{osm}}}
$$

where $k\left(\right.$ in s $\left.^{-1}\right)$ is the rate constant obtained by fitting the light scattered data to a simple exponential; $r$ is the liposome radius, measured by DLS; $v_{\mathrm{w}}$ is the partial molar volume of water $\left(0.018 \mathrm{~L} \cdot \mathrm{mol}^{-1}\right)$; and $\Delta_{\text {osm }}$ is the difference in osmolarity between the extra and the intravesicular compartment $(0.0785$ $\left.\mathrm{mol} \cdot \mathrm{L}^{-1}\right)$.

\section{ASSOCIATED CONTENT}

\section{Supporting Information}

The Supporting Information is available free of charge on the ACS Publications website at DOI: 10.1021/acsomega.7b00261.

SDS-PAGE showing the purified proteins (PDF)

\section{AUTHOR INFORMATION}

\section{Corresponding Authors}

*E-mail: victoria.schmidt@imm.cnrs.fr (V.S.).

*E-mail: james.sturgis@univ-amu.fr (J.N.S.).

ORCID

James N. Sturgis: 0000-0001-5125-7699

Notes

The authors declare no competing financial interest.

\section{ACKNOWLEDGMENTS}

The authors thank V. Prima, M. Sidore, J. Roche, and J. P. Duneau for technical assistance and many helpful discussions. This work was supported by the CNRS and Espoir contre la Mucoviscidose.

\section{REFERENCES}

(1) Preston, G. M.; Agre, P. Isolation of the cDNA for erythrocyte integral membrane protein of 28 kilodaltons: member of an ancient channel family. Proc. Natl. Acad. Sci. U.S.A. 1991, 88, 11110-11114.

(2) Agre, P.; Saboori, A. M.; Asimos, A.; Smith, B. L. Purification and partial characterization of the $M_{r} 30,000$ integral membrane protein associated with the erythrocyte $\mathrm{Rh}(\mathrm{D})$ antigen. J. Biol. Chem. 1987, 262, 17497-17503.

(3) Jung, J. S.; Preston, G. M.; Smith, B. L.; Guggino, W. B.; Agre, P. Molecular Structure of the Water Channel through Aquaporin CHIP. J. Biol. Chem. 1994, 269, 14648-14654. 
(4) Borgnia, M. J.; Kozono, D.; Calamita, G.; Maloney, P. C.; Agre, P. Functional reconstitution and characterization of AqpZ, the E. coli water channel protein. J. Mol. Biol. 1999, 291, 1169-1179.

(5) Sui, H.; Han, B.-G.; Lee, J. K.; Walian, P.; Jap, B. K. Structural basis of water-specific transport through the Aqp1 water channel. Nature 2001, 414, 872-878.

(6) Nielsen, S.; Agre, P. The aquaporin family of water channels in kidney. Kidney Int. 1995, 48, 1057-1068.

(7) Brown, D.; Katsura, T.; Kawashima, M.; Verkman, A. S.; Sabolic, I. Cellular distribution of the aquaporins: a family of water channel proteins. Histochem. Cell Biol. 1995, 104, 1-9.

(8) Fetter, K.; van Wilder, V.; Moshelion, M.; Chaumont, F. Interactions between Plasma Membrane Aquaporins Modulate Their Water Channel Activity. Plant Cell 2004, 16, 215-228.

(9) Arce, J.; Sturgis, J. N.; Duneau, J.-P. Dissecting membrane protein architecture: An annotation of structural complexity. Biopolymers 2009, 91, 815-829.

(10) Tsukihara, T.; Aoyama, H.; Yamashita, E.; Tomizaki, T.; Yamaguchi, H.; Shinzawa-Itoh, K.; Nakashima, R.; Yaono, R.; Yoshikawa, S. Structures of metal sites of oxidized bovine heart cytochrome c oxidase at $2.8 \AA$ Acience 1995, 269, 1069-1074.

(11) Vonck, J.; Schäfer, E. Supramolecular organization of protein complexes in the mitochondrial inner membrane. Biochim. Biophys. Acta, Mol. Cell Res. 2009, 1793, 117-124.

(12) Zhang, P.; Khursigara, C. M.; Hartnell, L. M.; Subramaniam, S. Direct visualization of Escherichia coli chemotaxis receptor arrays using cryo-electron microscopy. Proc. Natl. Acad. Sci. U.S.A. 2007, 104, 3777-3781.

(13) Hubert, P.; Sawma, P.; Duneau, J.-P.; Khao, J.; Hénin, J.; Bagnard, D.; Sturgis, J. Single-spanning transmembrane domains in cell growth and cell-cell interactions: More than meets the eye? Cell Adhes. Migr. 2010, 4, 313-324.

(14) Borgnia, M. J.; Agre, P. Reconstitution and functional comparison of purified GlpF and AqpZ, the glycerol and water channels from Escherichia coli. Proc. Natl. Acad. Sci. U.S.A. 2001, 98, 2888-2893.

(15) Calamita, G. The Escherichia coli Aquaporin-Z water channel. Mol. Microbiol. 2000, 37, 254-262.

(16) Gasteiger, E.; Hoogland, C.; Gattiker, A.; Duvaud, S.; Wilkins, M. R.; Appel, R. D.; Bairoch, A. Protein Identification and Analysis Tools on the ExPASy Server. In The Proteomics Protocols Handbook; Humana Press, 2005; pp 571-607.

(17) Klein, N.; Kümmerer, N.; Hobernik, D.; Schneider, D. The AQP2 mutation V71M causes nephrogenic diabetes insipidus in humans but does not impair the function of a bacterial homolog. FEBS Open Bio 2015, 5, 640-646.

(18) Cymer, F.; Schneider, D. A single glutamate residue controls the oligomerization, function, and stability of the aquaglyceroporin GlpF. Biochemistry 2010, 49, 279-286.

(19) Kitchen, P.; Conner, M. T.; Bill, R. M.; Conner, A. C. Structural Determinants of Oligomerization of the Aquaporin-4 Channel. J. Biol. Chem. 2016, 291, 6858-6871.

(20) Adair, B. D.; Engelman, D. M. Glycophorin A helical transmembrane domains dimerize in phospholipid bilayers: a resonance energy transfer study. Biochemistry 1994, 33, 5539-5544.

(21) Schneider, D. Rendezvous in a membrane: close packing, hydrogen bonding, and the formation of transmembrane helix oligomers. FEBS Lett. 2004, 577, 5-8.

(22) Kim, S.; Jeon, T.-J.; Oberai, A.; Yang, D.; Schmidt, J. J.; Bowie, J. U. Transmembrane glycine zippers: Physiological and pathological roles in membrane proteins. Proc. Natl. Acad. Sci. U.S.A. 2005, 102, $14278-14283$.

(23) Fisher, L. E.; Engelman, D. M.; Sturgis, J. N. Detergents modulate dimerization, but not helicity, of the glycophorin A transmembrane domain. J. Mol. Biol. 1999, 293, 639-651.

(24) Orzáez, M.; Lukovic, D.; Abad, C.; Pérez-Payá, E.; Mingarro, I. Influence of hydrophobic matching on association of model transmembrane fragments containing a minimised glycophorin A dimerisation motif. FEBS Lett. 2005, 579, 1633-1638.
(25) Adamian, L.; Liang, J. Interhelical hydrogen bonds and spatial motifs in membrane proteins: Polar clamps and serine zippers. Proteins: Struct., Funct., Genet. 2002, 47, 209-218.

(26) Robertson, J. L.; Kolmakova-Partensky, L.; Miller, C. Design, function and structure of a monomeric $\mathrm{ClC}$ transporter. Nature 2010, 468, 844-847.

(27) Chadda, R.; Krishnamani, V.; Mersch, K.; Wong, J.; Brimberry, M.; Chadda, A.; Kolmakova-Partensky, L.; Friedman, L. J.; Gelles, J.; Robertson, J. L. The dimerization equilibrium of a $\mathrm{CLC} \mathrm{CL}-/ \mathrm{H}^{+}$ antiporter in lipid bilayers. eLife 2016, 5, No. e17438.

(28) Gupta, K.; Donlan, J. A. C.; Hopper, J. T. S.; Uzdavinys, P.; Landreh, M.; Struwe, W. B.; Drew, D.; Baldwin, A. J.; Stansfeld, P. J.; Robinson, C. V. The role of interfacial lipids in stabilizing membrane protein oligomers. Nature 2017, 541, 421-424.

(29) Pan, Y.; Piyadasa, H.; O’Neil, J. D.; Konermann, L. Conformational dynamics of a membrane transport protein probed by $\mathrm{H} / \mathrm{D}$ exchange and covalent labeling: the glycerol facilitator. J. Mol. Biol. 2012, 416, 400-413.

(30) Krissinel, E.; Henrick, K. Inference of Macromolecular Assemblies from Crystalline State. J. Mol. Biol. 2007, 372, 774-797.

(31) Jones, S.; Thornton, J. M. Protein-protein interactions: A review of protein dimer structures. Prog. Biophys. Mol. Biol. 1995, 63, 31-65.

(32) Jones, S.; Thornton, J. M. Principles of protein-protein interactions. Proc. Natl. Acad. Sci. U.S.A. 1996, 93, 13-20.

(33) Schrödinger, L. L. C. The PyMOL Molecular Graphics System, version $1.8,2015$.

(34) Savage, D. F.; Egea, P. F.; Robles-Colmenares, Y.; O’Connell, J. D.; Stroud, R. M. Architecture and Selectivity in Aquaporins: $2.5 \AA$ XRay Structure of Aquaporin Z. PLoS Biol. 2003, 1, No. e72.

(35) Partridge, A. W.; Melnyk, R. A.; Deber, C. M. Polar residues in membrane domains of proteins: Molecular basis for helix-helix association in a mutant CFTR transmembrane segment. Biochemistry 2002, 41, 3647-3653.

(36) Curran, A. R.; Engelman, D. M. Sequence motifs, polar interactions and conformational changes in helical membrane proteins. Curr. Opin. Struct. Biol. 2003, 13, 412-417.

(37) Laganowsky, A.; Reading, E.; Allison, T. M.; Ulmschneider, M. B.; Degiacomi, M. T.; Baldwin, A. J.; Robinson, C. V. Membrane proteins bind lipids selectively to modulate their structure and function. Nature 2014, 510, 172-175.

(38) Klein, N.; Neumann, J.; O’Neil, J. D.; Schneider, D. Folding and stability of the aquaglyceroporin GlpF: implications for human aqua(glycero)porin diseases. Biochim. Biophys. Acta, Biomembr. 2015, $1848,622-633$.

(39) Borgnia, M. J.; Agre, P. Reconstitution and functional comparison of purified GlpF and AqpZ, the glycerol and water channels from Escherichia coli. Proc. Natl. Acad. Sci. U.S.A. 2001, 98, 2888-2893.

(40) Berthaud, A.; Manzi, J.; Pérez, J.; Mangenot, S. Modeling detergent organization around aquaporin-0 using Small-Angle X-ray Scattering. J. Am. Chem. Soc. 2012, 134, 10080-10088.

(41) Perez-Iratxeta, C.; Andrade-Navarro, M. A. K2D2: Estimation of protein secondary structure from circular dichroism spectra. $B M C$ Struct. Biol. 2008, 8, 25.

(42) Miles, A. J.; Wallace, B. A. Circular dichroism spectroscopy of membrane proteins. Chem. Soc. Rev. 2016, 45, 4859-4872.

(43) Greenfield, N. J. Using circular dichroism spectra to estimate protein secondary structure. Nat. Protoc. 2007, 1, 2876-2890.

(44) Klein, N.; Neumann, J.; O’Neil, J. D.; Schneider, D. Folding and stability of the aquaglyceroporin GlpF: Implications for human aqua(glycero)porin diseases. Biochim. Biophys. Acta, Biomembr. 2015, $1848,622-633$.

(45) Buck, T. M.; Wagner, J.; Grund, S.; Skach, W. R. A novel tripartite motif involved in aquaporin topogenesis, monomer folding and tetramerization. Nat. Struct. Mol. Biol. 2007, 14, 762-769.

(46) Popot, J. L.; Engelman, D. M. Membrane protein folding and oligomerization: the two-stage model. Biochemistry 1990, 29, 40314037. 
(47) Engelman, D. M.; Chen, Y.; Chin, C.-N.; Curran, A. R.; Dixon, A. M.; Dupuy, A. D.; Lee, A. S.; Lehnert, U.; Matthews, E. E.; Reshetnyak, Y. K.; Senes, A.; Popot, J.-L. Membrane protein folding: beyond the two stage model. FEBS Lett. 2003, 555, 122-125.

(48) Walz, T.; Smith, B. L.; Agre, P.; Engel, A. The three-dimensional structure of human erythrocyte aquaporin CHIP. EMBO J. 1994, 13, 2985-2993.

(49) Marr, N.; Kamsteeg, E. J.; van Raak, M.; van Os, C. H.; Deen, P. M. T. Functionality of aquaporin-2 missense mutants in recessive nephrogenic diabetes insipidus. Eur. J. Physiol. 2001, 442, 73-77.

(50) Jiang, J.; Daniels, B. V.; Fu, D. Crystal structure of AqpZ tetramer reveals two distinct Arg-189 conformations associated with water permeation through the narrowest constriction of the waterconducting channel. J. Biol. Chem. 2006, 281, 454-460.

(51) Rodier, F.; Bahadur, R. P.; Chakrabarti, P.; Janin, J. Hydration of protein-protein interfaces. Proteins: Struct., Funct., Bioinf. 2005, 60, 3645.

(52) Urakubo, Y.; Ikura, T.; Ito, N. Crystal structural analysis of protein-protein interactions drastically destabilized by a single mutation. Protein Sci. 2008, 17, 1055-1065.

(53) Duneau, J.-P.; Khao, J.; Sturgis, J. N. Lipid perturbation by membrane proteins and the lipophobic effect. Biochim. Biophys. Acta, Biomembr. 2017, 1859, 126-134.

(54) Barik, S. Site-directed mutagenesis by double polymerase chain reaction. Mol. Biotechnol. 1995, 3, 1-7.

(55) Erickson, H. P. Size and shape of protein molecules at the nanometer level determined by sedimentation, gel filtration, and electron microscopy. Biol. Proced. Online 2009, 11, 32-51.

(56) Karimova, G.; Robichon, C.; Ladant, D. Characterization of YmgF, a 72-Residue Inner Membrane Protein That Associates with the Escherichia coli Cell Division Machinery. J. Bacteriol. 2009, 191, 333346. 